\title{
THE DETERMINATION OF AMMONIA AND TOTAL IONIC INORGANIC NITROGEN IN SEA WATER
}

\author{
By J. P. RILEY and P. SINHASENI \\ The Department of Oceanography, The University, Liverpool
}

(Text-figs. I and 2)

Combined inorganic nitrogen occurs in sea water principally as nitrate, nitrite and ammonium ions, the concentrations of which lie in the ranges

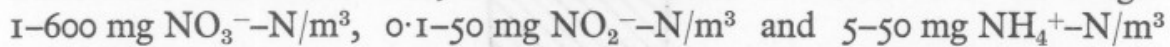
respectively. Nitrogen occurring in any of these forms is readily assimilable by marine organisms, and its exhaustion in sea water is frequently a growthlimiting factor in the water. This paper describes a method for the determination of the total ionic inorganic nitrogen in sea water, based on preliminary reduction to ammonia followed by separation and estimation of the latter colorimetrically.

Riley (I953) has discussed the determination of ammonia in sea water, and has concluded that ammonia is best separated from the water, adjusted to $\mathrm{pH} 9 \cdot 2$, by distillation under reduced pressure in a current of air as described by Krogh (1934). The distillation process is rather time-consuming and requires a special apparatus. Experiments were therefore carried out to separate the ammonia by diffusion. It was found that the capacity of the concentric microdiffusion cells employed by Conway (I950, p. 8) was too small for the volume of sea water which was necessary if low concentrations of ammonia were to be determined. When diffusion was carried out in the flasks (Fig. I) described by Cavett (1937) for the microdetermination of alcohol in blood, reproducible recoveries of approximately $73 \%$ of added ammonium salt were obtained from $50 \mathrm{ml}$. of sea water after diffusion at $70^{\circ} \mathrm{C}$ for $24 \mathrm{~h}$ at $\mathrm{pH} 9 \cdot 2$ (Table $\mathrm{I}$ ).

Much of the earliest work on the determination of nitrate in sea water was based on its reduction to ammonia, which was separated by distillation and determined by Nessler's method. Few of the reducing agents (magnesium, Raben, I905 $a$, sodium amalgam, Raben, 1905 $b$; aluminium amalgam, Raben, I9I0, I9I4; Devarda's alloy, Brandt, I927; iron-zinc couple, Thorpe \& Morton, I87I; aluminium and sulphuric acid, Gad-Andresen, I923) which have been used for this purpose are satisfactory if the ammonia is to be separated by diffusion, owing to the evolution of hydrogen which causes pressure to develop in the Cavett flask. Attempts to carry out the reduction using ferrous hydroxide and titanous salts gave very poor recoveries of ammonia. 
Raney nickel (semi-colloidal nickel prepared by the action of strong alkali on nickel-aluminium alloy) has been used by Van Dalen (I95I) as a catalyst in the hydrogenation of macro amounts of nitrate to ammonia. Since the catalytic nickel contains up to $\mathrm{I} 20 \mathrm{ml}$. H/g (Mozingo, Wolf, Harris \& Folkes, I943) it was thought that microgram quantities of nitrate could be reduced to

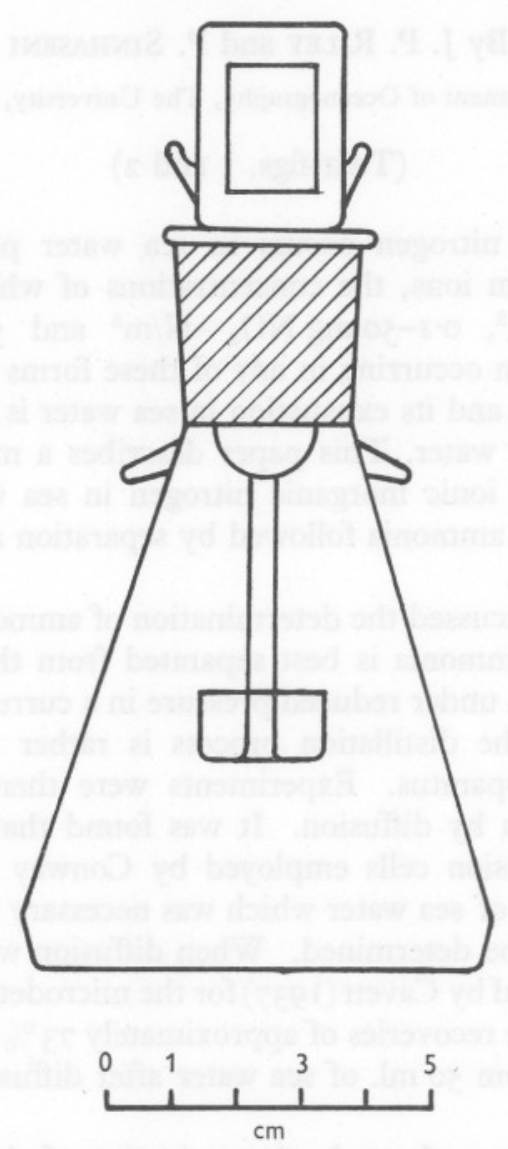

Fig. I. A Cavett flask as used for the microdiffusion of ammonia.

TABLE 1. RECOVERY OF AMMONIA FROM $50 \mathrm{ML}$. OF SEA WATER CONTAINING ADDED AMMONIUM SULPHATE AND IOML. OF METABORATE BUFFER DIFFUSED AT $70^{\circ} \mathrm{C}$ FOR $20 \mathrm{H}$.

\begin{tabular}{|c|c|c|}
\hline \multicolumn{2}{|c|}{$\mu \mathrm{g} \mathrm{NH}_{4}{ }^{+}-\mathrm{N}$} & \multirow{2}{*}{$\begin{array}{l}\text { Mean } \\
\text { recovery } \\
(\%)\end{array}$} \\
\hline Added & Found & \\
\hline 0.0 & 0.0 & - \\
\hline 2.5 & $\mathrm{I} \cdot 7 \mathrm{I} \cdot 7 \mathrm{I} \cdot 8$ & 69 \\
\hline $5 \cdot 0$ & 3.53 .63 .63 .7 & 72 \\
\hline $10 \cdot 0$ & $7 \cdot 27.5$ & 73 \\
\hline
\end{tabular}


ammonia by the action of its adsorbed hydrogen. This proved to be the case. It was found that the reduction proceeded much more rapidly in the presence of ethylenediamine-tetraacetic acid (EDTA) which also served to reduce the quantity of magnesium and calcium salts precipitated from the sea water at the $\mathrm{pH}$ of 10.5 used in the reduction and diffusion.

\section{COLORIMETRIC DETERMINATION OF AMMONIA}

The advantages of the phenate-hypochlorite method over the Nessler method for the colorimetric determination of ammonia have been enumerated by Riley (1953). Crowther \& Large (1956) have found that the indophenol-blue colour develops rapidly at room temperature if the sodium phenate reagent is made up in an aqueous mixture of acetone and methyl alcohol instead of water.

TABLE 2. EFFECT OF VARIATION OF VOLUMES OF SODIUM PHENATE AND SODIUM HYPOCHLORITE REAGENTS ON OPTICAL DENSITIES OF SOLUTIONS MEASURED AT $625 \mathrm{M} \mu$ IN A I CM CELL $\left(\right.$ IO $\mu \mathrm{G} \mathrm{NH}_{4}{ }^{+}-\mathrm{N}$ IN FINAL VOLUME OF Io ML.)

$\begin{array}{lllllll}\text { ml. of hypochlorite* } & 0.5 & 1.0 & 1.5 & 2.0 & 2.5 & 3.0 \\ 0.5 \mathrm{ml} \text {. of phenate } & 0.387 & 0.340 & 0.280 & 0.234 & 0.185 & 0.165 \\ \text { I.0 ml. of phenate } & 0.372 & 0.380 & 0.373 & 0.370 & 0.350 & 0.328 \\ \text { I.5 ml. of phenate } & 0.273 & 0.320 & 0.337 & 0.370 & 0.365 & 0.352 \\ 2.0 \mathrm{ml} \text {. of phenate } & 0.163 & 0.280 & 0.310 & 0.340 & 0.355 & - \\ & \star 0.9 \% \text { available chlorine. } \\ & \text { † In methanol containing acetone. }\end{array}$

In order to find the optimum conditions for the determination of ammonia using Crowther's reagent, determinations were carried out using Io $\mu \mathrm{g} \mathrm{NH}_{4}{ }^{+}-\mathrm{N}$ and varying the amounts of both sodium phenate (prepared according to Crowther \& Large, 1956) and sodium hypochlorite added. The optical densities of the solutions were measured at $625 \mathrm{~m} \mu$ after $\mathrm{I} h$. The results, which are given in Table 2, indicated that $\mathrm{I} \mathrm{ml}$. of sodium phenate and $\mathrm{I} .5 \mathrm{ml}$. of sodium hypochlorite were the most suitable volumes. Under these conditions, which were adopted for all subsequent work, the maximum optical density was attained after $45 \mathrm{~min}$ at $20^{\circ} \mathrm{C}$, and remained constant for a further $60 \mathrm{~min}$, after which time slow fading occurred.

A calibration curve was prepared using known amounts of ammonium salt (Fig. 2); it indicated that Beer's law is obeyed up to a concentration of I. $5 \mu \mathrm{g} \mathrm{NH}_{4}{ }^{+}-\mathrm{N} / \mathrm{ml}$. (in a final volume of $10 \mathrm{ml}$.). Above this concentration the change in optical density per unit weight of $\mathrm{NH}_{4}{ }^{+}-\mathrm{N}$ is considerably reduced. Replicate determinations (6) carried out with 5 and $\mathrm{Io} \mu \mathrm{g} \mathrm{NH}_{4}{ }^{+}-\mathrm{N}$ gave mean optical densities (less blank) of $0.190 \pm 0.001$ and $0.377 \pm 0.002$. 


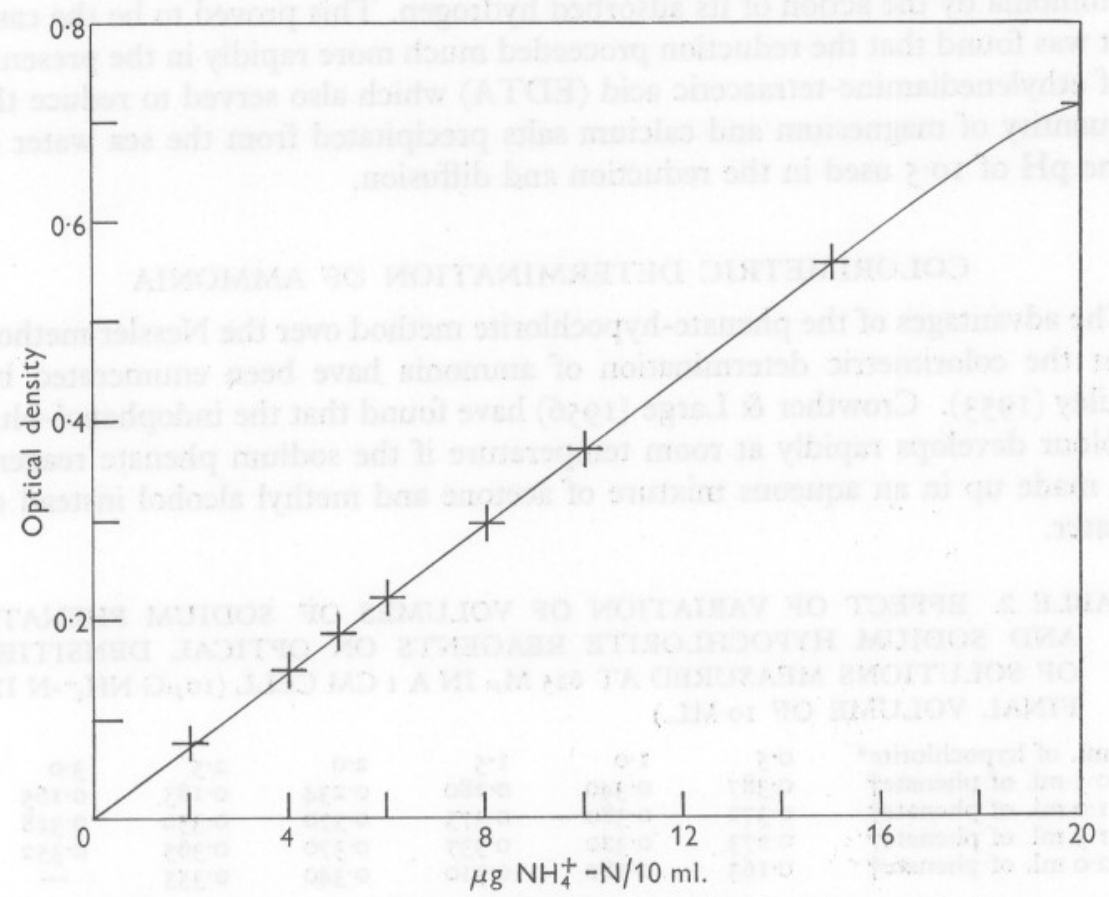

Fig. 2. Calibration chart of the method for the determination of ammonia in sea water, prepared by using known amounts of ammonia. Optical density at $625 \mathrm{~m} \mu$ using a $\mathrm{I} \mathrm{cm}$ cell.

\section{METHOD}

All measurements of optical density were made with a Unicam S.P. 500 spectrophotometer using $\mathrm{I} \mathrm{cm}$ glass cells, against distilled water in the compensating cell.

\section{REAGENTS}

All reagents and solutions must be made up with water which has been freshly distilled from dilute sulphuric acid in an all-glass still.

\section{Metaborate buffer}

Dissolve $2.55 \mathrm{~g}$ of sodium metaborate and $2.0 \mathrm{~g}$ of sodium hydroxide in distilled water, dilute to $100 \mathrm{ml}$.

\section{Raney nickel}

Weigh out c. $5 \mathrm{~g}$ of powdered nickel-aluminium alloy, (50/50) and add it gradually to a $250 \mathrm{ml}$. beaker containing a solution of $\mathrm{ro} \mathrm{g}$ of sodium hydroxide in $70 \mathrm{ml}$. of distilled water. After the addition has been completed, heat the covered beaker on a hot plate for $30 \mathrm{~min}$, when all effervescence should have 
ceased. Wash the finely divided nickel with hot water by decantation, until the washings are free from alkali. Preserve it under water and do not allow it to become dry. Fresh Raney nickel should be prepared at least weekly.

Caution: care should be taken when disposing of waste Raney nickel as it is pyrophoric when dry.

\section{EDTA reagent}

Dissolve $4 \mathrm{~g}$ of ethylenediamine-tetraacetic acid (disodium salt) in $100 \mathrm{ml}$. of distilled water.

\section{Sodium hydroxide $(2 \mathrm{~N})$}

Gently boil a solution of $8 \mathrm{~g}$ of sodium hydroxide in $60 \mathrm{ml}$. of water for a few minutes. When cool, dilute to $100 \mathrm{ml}$.

\section{Hydrochloric acid $(0.02 \mathrm{~N})$}

Dilute $2 \mathrm{ml}$. of concentrated hydrochloric acid to $1000 \mathrm{ml}$.

\section{Sodium phenate reagent}

(a) Phenol solution (solution A). Dissolve $62.5 \mathrm{~g}$ of phenol B.P. in methyl alcohol, add $20 \mathrm{ml}$. of acetone and dilute to $100 \mathrm{ml}$. with methyl alcohol. The reagent, which should be prepared each week, must be kept in a refrigerator.

(b) Sodium hydroxide (solution B). Dissolve $27 \mathrm{~g}$ of sodium hydroxide A.R. in c. $60 \mathrm{ml}$. of distilled water, boil gently for a few minutes to remove ammonia, cool and dilute to $100 \mathrm{ml}$.

For use mix $20 \mathrm{ml}$. portions of solutions A and B and dilute to $100 \mathrm{ml}$. The mixed reagent should be prepared freshly as required.

\section{Sodium hypochlorite reagent}

The reagent solution is prepared by dilution of commercial sodium hypochlorite solution and contains $0.9 \mathrm{~g}$ of available chlorine per $100 \mathrm{ml}$. The strength of the stock solution should be checked periodically.

\section{Ammonium sulphate}

STANDARD SOLUTIONS

Weigh out $0.4716 \mathrm{~g}$ of ammonium sulphate A.R., dissolve in water and dilute to $1000 \mathrm{ml}$. This solution, which contains $100 \mu \mathrm{g} \mathrm{NH}_{4}{ }^{+}-\mathrm{N} / \mathrm{ml}$. is used for the preparation of the working solution containing $2 \cdot 5 \mu \mathrm{g}$. $\mathrm{NH}_{4}{ }^{+}-\mathrm{N} / \mathrm{ml}$.

\section{Potassium nitrate}

Prepare a solution of potassium nitrate containing ro $\mu \mathrm{g} \mathrm{NO}_{3}{ }^{-}-\mathrm{N} / \mathrm{ml}$. by dissolving $0.0722 \mathrm{~g}$ of the A.R. grade salt in water and diluting to $1000 \mathrm{ml}$. Prepare from this a working solution containing $2.5 \mu \mathrm{g} \mathrm{NO}_{3}{ }^{-}-\mathrm{N} / \mathrm{ml}$. 


\section{Sodium nitrite}

Dissolve 0.1099 $\mathrm{g}$ of recrystallized silver nitrite in about $10 \mathrm{ml}$. of boiling water, and add while still hot c. O.IO g of sodium chloride. Shake until the silver chloride flocculates, set aside in the dark until the solution has cleared. Dilute to $1000 \mathrm{ml}$. From this solution, which contains $10 \mu \mathrm{g} \mathrm{NO}_{2}{ }^{-} \mathrm{N} / \mathrm{ml}$, prepare a working solution containing $2 \cdot 5 \mu \mathrm{g}$. $\mathrm{NO}_{2}{ }^{-}-\mathrm{N} / \mathrm{ml}$.

\section{TREATMENT OF FLASKS}

Wash all Cavett flasks and graduated flasks with concentrated hydrochloric acid. Rinse with distilled water, then with $0.1 \mathrm{~N}$ sodium hydroxide and again with water, allow them to drain. Lubricate the upper part of the ground surface of the Cavett flask stoppers with a mixture of equal weights of paraffin wax (congealing point $49^{\circ} \mathrm{C}$ ) and medicinal paraffin.

\section{DETERMINATION OF AMMONIA IN SEA WATER}

Pipette $50 \mathrm{ml}$. of filtered sea water into a $150 \mathrm{ml}$. conical flask fitted with a B 24 socket, add $2 \mathrm{ml}$. of $4 \%$ EDTA reagent and raise to boiling on the hot plate. Remove from the heater and add c. $2 \mathrm{ml}$. of sodium metaborate buffer from a fast running pipette. Immediately close the flask with a lubricated Cavett stopper (Quickfit and Quartz Catalogue No. $\mathrm{BC}_{3} \mathrm{CH}$ ), the cup of which contains I ml. of $0.02 \mathrm{~N}$ hydrochloric acid. Gently shake the stoppered flask and then heat in an oven at $70^{\circ} \mathrm{C}$. After $24 \mathrm{~h}$ remove the flask from the oven and allow to cool for a few minutes. Transfer the hydrochloric acid in the cup to a ro ml. graduated flask by means of a drawn-out glass tube fitted with a rubber teat. Wash the cup well with distilled water and transfer the washings to the graduated flask. To the combined solutions add $\mathrm{I} \mathrm{ml}$. of sodium phenate reagent and $\mathrm{I} \cdot 5 \mathrm{ml}$. of sodium hypochlorite solution, dilute to volume and mix thoroughly. After $45-60$ min measure the optical density at $625 \mathrm{~m} \mu$. Run a reagent blank on Io $\mathrm{ml}$. of distilled water in the same manner. Calibrate the method by carrying out a determination on $50 \mathrm{ml}$. of the same sea water to which $5 \mu \mathrm{g} \mathrm{\textrm {NH } _ { 4 }}{ }^{+}-\mathrm{N}$ has been added.

\section{DETERMINATION OF TOTAL IONIC INORGANIC NITROGEN IN SEA WATER}

Pipette $50 \mathrm{ml}$. of sea water into a $150 \mathrm{ml}$. conical flask fitted with a B 24 socket, add from a small scoop $c .0 .2 \mathrm{~g}$ of Raney nickel and $\mathrm{I} \mathrm{ml}$. of $4 \%$ EDTA reagent. Heat the solution on a hot plate and allow to boil gently for $15 \mathrm{~min}$. Remove from the heater and add rapidly $2 \mathrm{ml}$. of $2 \mathrm{~N}$ sodium hydroxide. Immediately close the flask with a well-lubricated Cavett stopper, the cup of which contains I ml. of $0.02 \mathrm{~N}$ hydrochloric acid. Place in an oven at $70^{\circ} \mathrm{C}$ to allow the ammonia to diffuse. After $24 \mathrm{~h}$ determine the ammonia as described above. 
Carry out a blank determination on $\mathrm{ro} \mathrm{ml}$. of distilled water and a calibration run on the same sea water, to which has been added $5 \mu \mathrm{g} \mathrm{NO}_{3}{ }^{-}$or $\mathrm{NO}_{2}{ }^{-}-\mathrm{N}$.

Great care must be taken to avoid contamination by extraneous nitrogen compounds during the determination; in particular, the apparatus should not be handled more than is absolutely necessary.

It is important also to take approximately the same amount of Raney nickel in each determination and in the blank, since it always yields small amounts of ammonia during the diffusion.

\section{RESULTS}

In order to test the recovery of nitrogen from sea water, samples of sea water very low in inorganic nitrogen were enriched by the addition of known amounts of nitrate, nitrite, or ammonium-nitrogen. These samples were then analyzed for total nitrogen as described on p. 166. The results are shown in Table 3. They show that the reduction is complete since a recovery of $73 \pm 4 \%$

TABLE 3. RECOVERY OF INORGANIC NITROGEN FROM SEA WATER

\begin{tabular}{|c|c|c|c|c|c|c|c|c|c|c|}
\hline Nitrogen added & \multicolumn{8}{|c|}{ Nitrogen recovered $(\mu \mathrm{g} \mathrm{N})$} & $\begin{array}{l}\text { Average } \\
\text { recovery }\end{array}$ & $\begin{array}{l}\text { Percentage } \\
\text { recovery }\end{array}$ \\
\hline Sea water only & \multicolumn{8}{|c|}{ o } & $\circ$ & - \\
\hline $2.5 \mu \mathrm{g} \mathrm{NH}_{4}{ }^{+}-\mathrm{N}$ & $I \cdot 9$ & I.9 & $I \cdot 7$ & $\mathrm{I} \cdot 8$ & $\mathrm{I} \cdot 7$ & $2 \cdot 0$ & $2 \cdot 0$ & & $\mathrm{I} \cdot 86$ & 74 \\
\hline $5 \cdot 0 \mu \mathrm{g} \mathrm{NH}_{4}+-\mathrm{N}$ & 3.5 & 3.4 & 3.3 & 3.6 & 3.5 & 3.6 & & & 3.48 & 70 \\
\hline IO. $0 \mu \mathrm{g} \mathrm{NH}_{4}^{+}-\mathrm{N}$ & $7 \cdot 6$ & $7 \cdot 6$ & $7 \cdot 5$ & $7 \cdot 5$ & $7 \cdot 3$ & $7 \cdot 7$ & & & 7.53 & 75 \\
\hline $2.5 \mu \mathrm{g} \mathrm{NO}_{3}{ }^{-}-\mathrm{N}$ & $2 \cdot 0$ & $\mathrm{I} \cdot 7$ & $\mathrm{I} \cdot 8$ & $2 \cdot I$ & $2 \cdot I$ & $1 \cdot 9$ & & & $1 \cdot 92$ & 77 \\
\hline $5.0 \mu \mathrm{g} \mathrm{NO}_{3}{ }^{-}-\mathrm{N}$ & 3.5 & 3.7 & $3 \cdot 7$ & $3 \cdot 6$ & $3 \cdot 7$ & & & & $3 \cdot 64$ & 73 \\
\hline $10.0 \mu \mathrm{g} \mathrm{NO}_{3}{ }^{-}-\mathrm{N}$ & $7 \cdot I$ & $7 \cdot 3$ & 7.5 & $7 \cdot 7$ & $7 \cdot 6$ & $7 \cdot 7$ & $7 \cdot 2$ & $7 \cdot 3$ & $7 \cdot 42$ & 74 \\
\hline $2.5 \mu \mathrm{g} \mathrm{\textrm {NO } _ { 2 } - \mathrm { N }}$ & I. 5 & $\mathrm{I} \cdot 7$ & $\mathrm{I} \cdot \overline{8}$ & & & & & & $1 \cdot 69$ & 68 \\
\hline $5.0 \mu \mathrm{g} \mathrm{NO}{ }^{-}-\mathrm{N}$ & $3 \cdot 8$ & $3 \cdot 9$ & $3 \cdot 3$ & $3 \cdot 7$ & $3 \cdot 4$ & $3 \cdot 4$ & $3 \cdot 9$ & & 3.62 & 72 \\
\hline $10 \cdot 0 \mu \mathrm{g} \mathrm{NO}_{2}^{-}-\mathrm{N}$ & $7 \cdot 5$ & $7 \cdot 3$ & $7 \cdot 6$ & $7 \cdot 9$ & & & & & $7 \cdot 58$ & 76 \\
\hline & & & & & & & & & & ean $73 \%$ \\
\hline
\end{tabular}

of nitrate, nitrite and ammonium-nitrogen can be obtained using a diffusion time of $24 \mathrm{~h}$. Higher recoveries can be obtained with longer diffusion periods, but the results are less reproducible. Using the recommended conditions, replicate determinations (7) were carried out on a sample of Irish Sea water; they showed that the water contained $240 \mu \mathrm{g} \mathrm{N} / 1$. with a coefficient of variation of $2.5 \%$.

In order to investigate the possible interference which might be caused by the breakdown of organic nitrogen compounds during the diffusion, the determination was carried out in the presence of a number of typical organic nitrogen compounds. No interference was experienced using $20 \mu \mathrm{g}$ of DL- $\alpha-$ alanine, L-arginine hydrochloride, cystine, glutamic acid, urea, or choline chloride. 


\section{SUMMARY}

Microdiffusion using a Cavett flask has been employed instead of vacuum distillation for the separation of ammonia from sea water; diffusion is approximately $75 \%$ complete after $24 \mathrm{~h}$ at $70^{\circ} \mathrm{C}$. The recovered ammonia is determined by a modification of the phenate-hypochlorite method.

Raney nickel in the presence of ethylenediamine-tetraacetic acid has been used for the reduction of nitrate and nitrite to ammonia. The latter is separated by microdiffusion and determined colorimetrically. The method showed a coefficient of variation of $2.5 \%$ on a sample of sea water containing

$$
240 \mu \mathrm{g} \mathrm{NO}_{2}{ }^{-}+\mathrm{NO}_{3}{ }^{-}+\mathrm{NH}_{4}{ }^{+}-\mathrm{N} / 1 \text {. }
$$

No interference was encountered from a variety of organic nitrogen compounds.

\section{REFERENCES}

BRANDT, K., 1927. Stickstoffverbindungen im Meere I. Wiss. Meeresunters. (Abt. Kiel), Bd. 20, p. 212.

CAVETT, J. W., I937. The determination of alcohol in blood and other body fluids. 7. Lab. clin. Med., Vol. 23, pp. 543-6.

Conway, E. J., 1950. Microdiffusion Analysis and Volumetric Error, 3rd ed. 391 pp. London: Crosby Lockwood.

CROWTHER, A. B. \& LARGE, R. S., 1956. Improved conditions for the sodium-phenoxide-sodium hypochlorite method for the determination of ammonia. Analyst, Vol. 81, p. 64.

GAD-ANDRESEN, K. L., I923. A method for quantitative determination of ammonia, nitrate and nitrite, together with other nitrogenous compounds in sea-water. Publ. Circ. Cons. Explor. Mer, No. 82, pp. 14-17.

KROGH, A., 1934. A method for the determination of ammonia in water and air. Biol. Bull., Woods Hole, Vol. 57, pp. I26-31.

Mozingo, R., Wolf, D. E., Harris, S. A. \& Folkes, K., I943. Hydrogenolysis of sulphur compounds by Raney nickel catalyst. F. Amer. chem. Soc., Vol. 65, p. IOI3.

RABEN, E., I905a. Weitere Mitteilungen über quantitative Bestimmungen von Stickstoffverbindungen und gelöster Kieselsäure im Meerwasser. Wiss. Meeresunters. (Abt. Kiel), Bd. 8, pp. 279-80.

RABEN, E., $1905 b$. Über quantitative Bestimmung von Stickstoffverbindungen im Meerwasser. Wiss. Meeresunters. (Abt. Kiel), Bd. 8, pp. 8I-98.

RaBEN, E., I9I0. Dritte Mitteilung über quantitative Bestimmungen von Stickstoffverbindungen und von gelöster Kieselsäure im Meerwasser. Wiss. Meeresunters. (Abt. Kiel), Bd. II, pp. 305-I9.

RABEN, E., I914. Vierte Mitteilung über quantitative Bestimmungen von Stickstoffverbindungen im Meerwasser und Boden sowie von gelöster Kieselsäure im Meerwasser. Wiss. Meeresunters. (Abt. Kiel), Bd. 16, pp. 207-29.

RILEY, J. P., 1953. The spectrophotometric determination of ammonia in natural waters, with particular reference to sea-water. Anal. chim. acta, Vol. 9, pp. 575-89.

THORPE, T. E. \& MORTON, E. H., I871. Über das Wasser des Irländischen Meeres. Liebig's Ann. Chem., Bd. 158, dp. 122-31.

VAN DALEN, E., I95I. Schnelle Bestimmung von Nitrat in lösung mittels katalytischer Reduktion mitt Wasserstoff. Anal. chim. acta, Vol. 5, pp. 463-71. 